\title{
Characterization of Leachate and its Effects on Ground Water Quality Around Jawaharnagar Municipal Open Dumpsite, Rangareddy, Telangana
}

\author{
B. SOUJANYA KAMBLE \\ Department Of Environmental Science, University College Of Sciences, \\ Osmania University,Hyderabad - 500007, India. \\ http://dx.doi.org/10.12944/CWE.11.1.15
}

(Received: March 02, 2016; Accepted: March 25, 2016)

\begin{abstract}
In the present work, characterization of leachate from an open dumpsite, Jawaharnagar, Rangareddy district, Telangana and its effects on surrounding ground water was investigated. A total of one leachate sample and twelve ground water samples were collected during pre-monsoon and post-monsoon seasons (2015) for monitoring purpose. All the samples were analyzed for physicochemical parameters ( $\mathrm{pH}, \mathrm{TDS}, \mathrm{TH}, \mathrm{CH}, \mathrm{Cl}^{-}, \mathrm{SO}_{4}^{-2}, \mathrm{NO}_{3}^{-}$and $\mathrm{F}^{-}$) as per standard procedures (APHA). Results indicate that, only $\mathrm{pH}$ and sulphates were found to be within the permissible limits in ground water recommended by WHO:2006. Total dissolved solids, Chlorides and Nitrate levels were found to be alarming in both pre and post monsoon. Water quality index (WQI) study also showed that most of the water samples fall in "Poor" and "Unsuitable" category. It is evident that the leachate from the municipal dumpsite is polluting the ground water at greater extent making them unsuitable for drinking purpose. Therefore, immediate measures should be taken to control the leachate contamination in the ground water.
\end{abstract}

Key words: Jawaharnagar Dumpsite, Water Quality Index (WQI),

Physico-chemical parameters, WHO (2006).

\section{INTRODUCTION}

Management of solid waste and related environmental impacts presents a challenge to both developing and developed countries. Rapid industrialization, growing population and changing lifestyle are the root causes for increasing rate of solid waste generation. The quantum of municipal solid waste generated in India is about 0.15 million tons per day. This is approximately 50 million tons annually. Out of the total municipal waste collected, on an average $94 \%$ is dumped on land and $5 \%$ is composted. However, the average rate of MSW generation in India (0.35 to $0.60 \mathrm{~kg} /$ person/day) is very low as compared to developed countries ${ }^{1}$. The most widely used method for disposal of municipal solid waste is land filling. Landfills or open dumps are tremendously used for disposal of solid waste because they have capacity to accumulate large amounts of wastes offering very low cost as compared to incineration. For a long time, land filling was the most common waste management option for Municipal Solid Wastes (MSW). Not only is it a waste of resources but landfills as such constitute a health hazard and an environmental burden ${ }^{2}$. Unconditional dumping of municipal solid wastes results in generation of toxic leachate, which percolates through the soil and finally reaches the water table 
affecting the ground waters. As the ground water is an important part of the hydrological cycle, it is more prone to various sources of contamination. Amongst the drawbacks, landfills have been identified as one of the major threats to ground water resources ${ }^{3}$. Not only ground water resources, it equally affects the surface water bodies through the lateral movement of surface run-off as a result of precipitation. The toxic leachate may consists of large amounts of organic and inorganic compounds ${ }^{4}$. In countries like India, where ground water is a major source of water supply for drinking and domestic purpose if leachate is not controlled it can contaminate the surrounding soils, vegetation, livestock, surface waters and ultimately the ground water. Ground water treatment of polluted aquifers is inefficient in terms of economy and is time consuming. Further, the contaminants may still remain in aquifers even after prolonged process of remediation. Therefore regular monitoring of the wells in terms of quality assessment is mandatory to control the pollution to the earliest either experimentally or through mathematical modeling. Therefore, a seasonal evaluation of groundwater quality was carried out in order to determine the status of the water for human consumption as well as to provide overall scenario of ground water contamination around the dumpsites which opens an avenue for establishment of well engineered landfill to achieve ground water sustainability. WQI is an important technique for demarcating water quality and its suitability for drinking purposes. It is defined as a technique of rating that provides the composite influence of individual water quality parameters on the overall quality of water for human consumption ${ }^{5}$. It is one of the aggregate indices that have been accepted as a rating that reflects the composite influence on the overall quality of water quality characteristics. Higher value of WQI indicates better quality of water and lower value shows poor water quality. WQI helps us to translate multifaceted water quality data into simple information that is comprehensible and useable by the public. Several studies were carried out in order to estimate the water quality of ground waters around dumpsites during pre-monsoon and post monsoon seasons using WQI index ${ }^{6,78,9,10}$. The main focus of this study was to assess the physical and chemical parameters of ground waters during pre and post monsoon, 2015.

\section{MATERIALS AND METHODS}

\section{Study Location}

Jawaharnagar village dumpsite is located just outside the limits of GHMC (Greater Hyderabad Municipal Corporation) and inside the HMDA (New limits of Hyderabad). The site is $35 \mathrm{~km}$ from Hyderabad city and $105 \mathrm{~km}$ away from the state highway connecting Hyderabad and Nagpur in west direction from boundary of project site. It is an open dumpsite where unconditionally the solid wastes are dumped on a terraneous site called IrlaGutta (Gutta=Hill). The total area of Jawaharnagar dumpsite is 350 acres. The site receives Municipal Solid Waste of 5000 metric tons per day. It is located between 17 Ú291 $21^{11} \mathrm{~N}$ to 17 Ú3 $31^{13} 39^{11} \mathrm{~N}$ latitude and 78Ú34'13" E to 78Ú37'47"E longitude (Fig:1). It has a tropical wet and dry climate bordering on a hot semi-arid climate. The annual mean temperature is $26^{\circ} \mathrm{C}\left(78.8^{\circ} \mathrm{F}\right)$. Summers (March-June) are hot and humid. Maximum temperatures often exceed $40{ }^{\circ} \mathrm{C}\left(104^{\circ} \mathrm{F}\right)$ between April and June. Winter lasts for only about $2{ }^{1} \mathrm{D}_{2}$ months, during which the lowest temperature occasionally dips to $10^{\circ} \mathrm{C}$ $\left(50^{\circ} \mathrm{F}\right)$ in December and January. May, the hottest has temperatures ranging from 26 to $38.8{ }^{\circ} \mathrm{C}$. January, the coldest, has temperatures varying from 14 to $28{ }^{\circ} \mathrm{C}$. Heavy rain from the southwest summer monsoon falls between June and September, supplying Rangareddy with most of its annual rainfall of $812.5 \mathrm{~mm}$ (32 in). Monthly rainfall distribution of the sampling year (2015) in Rangareddy district is presented in (Fig:2).Geology of area comprises of pink and grey granite rock formations.

\section{Sample Collection}

Leachate sample was collected in 1 litre pre-cleaned high density polyethylene bottle (HDPE) with diluted $\mathrm{HNO}_{3}$ during pre-monsoon and post monsoon (2015) and was stored in the laboratory at $4 \mathrm{C}$ for monitoring purpose within 2 days. Similarly, ground water samples were collected from 12 stations during pre and post-monsoon within $5 \mathrm{~km}$ radius from the dumpsite employing random sampling method. Geographic locations, latitude, longitude of the sampling points were collected with the help of GARMIN GPS and the details are given in (Table:1). Each of the leachate and ground 
water samples were analyzed for 8 parameters viz., pH, TDS, $\mathrm{TH}, \mathrm{CH}, \mathrm{Cl}^{-}, \mathrm{SO}_{4}^{-2}, \mathrm{NO}_{3}^{-}$and $\mathrm{F}^{-}$using standard procedures recommended by ${ }^{11}$. The $\mathrm{pH}$ was recorded on site at the time of sampling with digital $\mathrm{pH}$ meter (HANNA Inst. Italy). The physicochemical parameters like Total Dissolved Solids (TDS), Total Hardness (TH), Calcium hardness $(\mathrm{CH})$ and Chlorides $(\mathrm{Cl})$ of leachate, and ground water

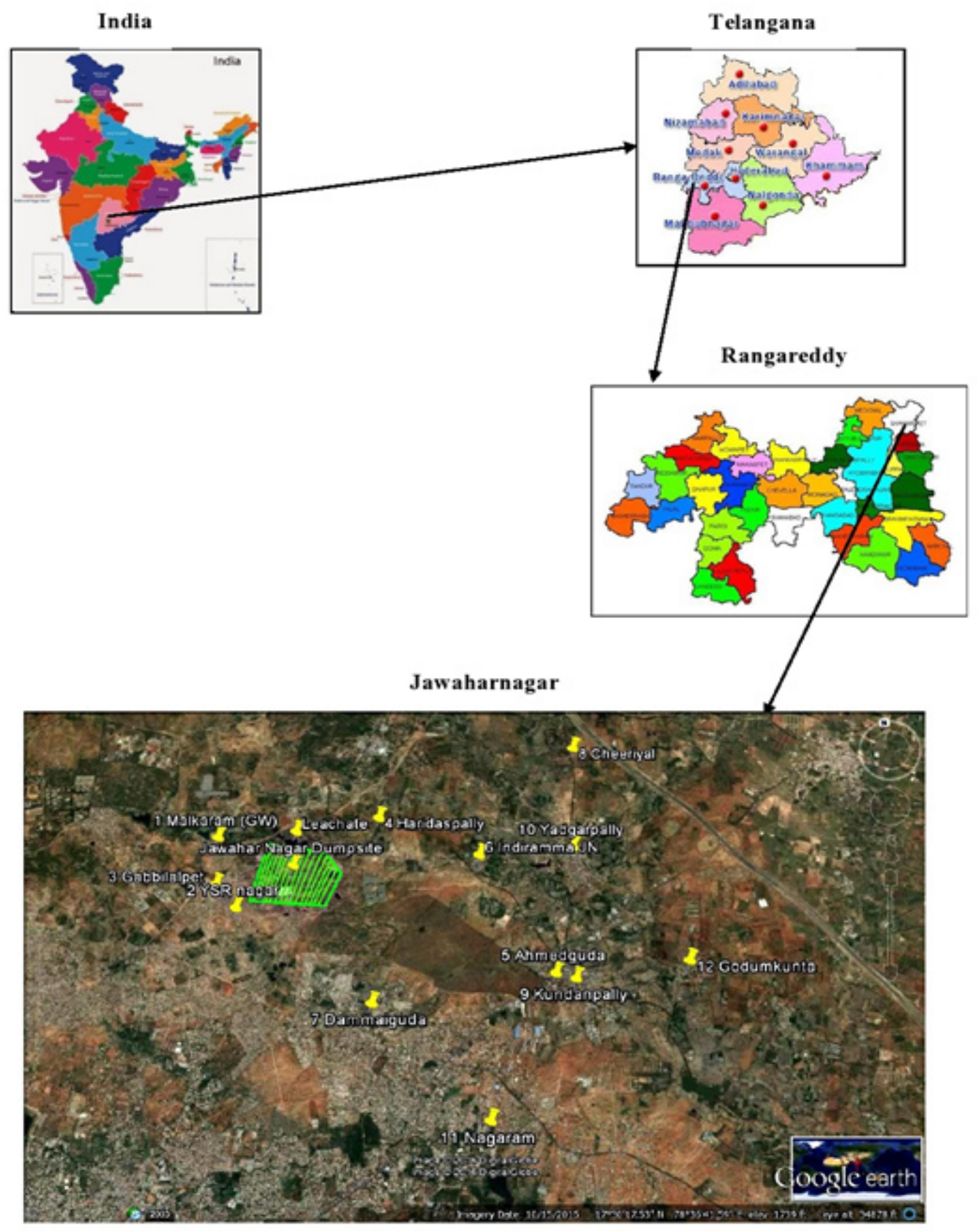

Fig. 1: Location Map of Study Area 
samples were analyzed titrimetrically. Chloride was included in the water quality assessment because of its measure of extent of dispersion of leachates in groundwater body ${ }^{12}$. Nitrates and Fluoride determination was carried out using lon-Selective Electrode (Orion). Sulfates $\left(\mathrm{SO}_{4}^{-2}\right)$ in the groundwater samples were analyzed by nephelometric turbidity method.

\section{Calculation of Water Quality Index}

In this study, for the calculation of WQI, eight important parameters were chosen. The WQI

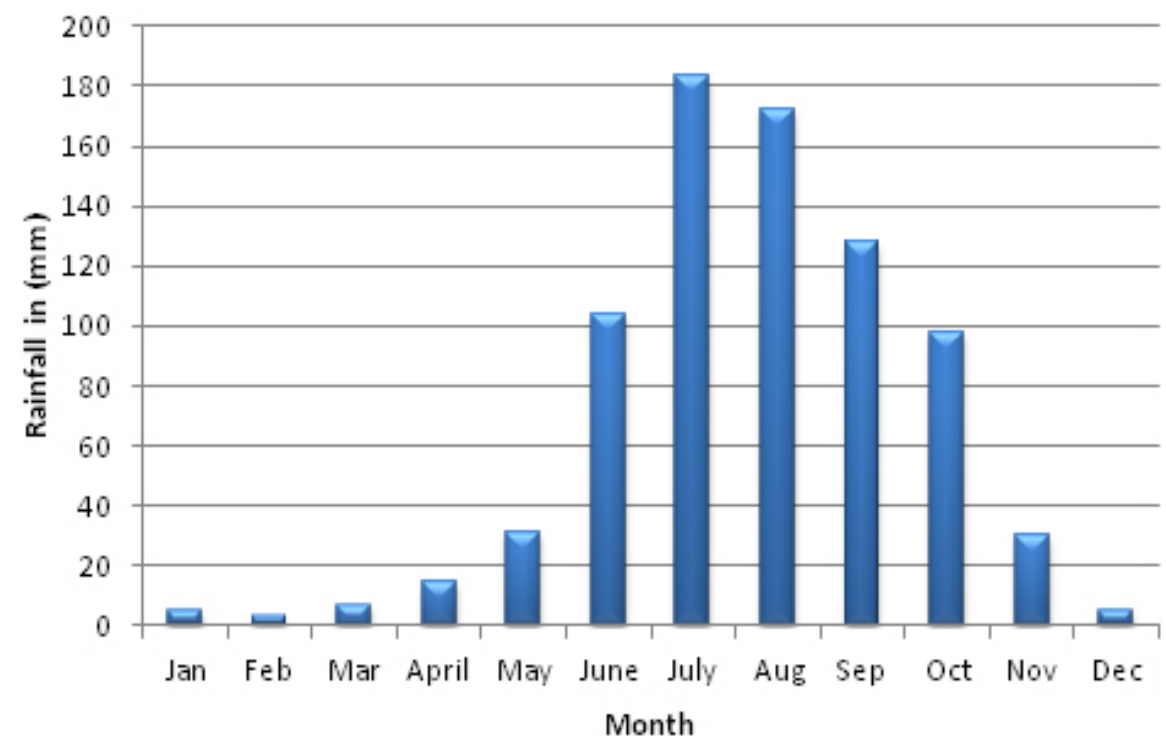

Fig. 2: Monthly Rainfall Distribution of Ranga Reddy District Source: Ground Water Department, Telangana State (2015)

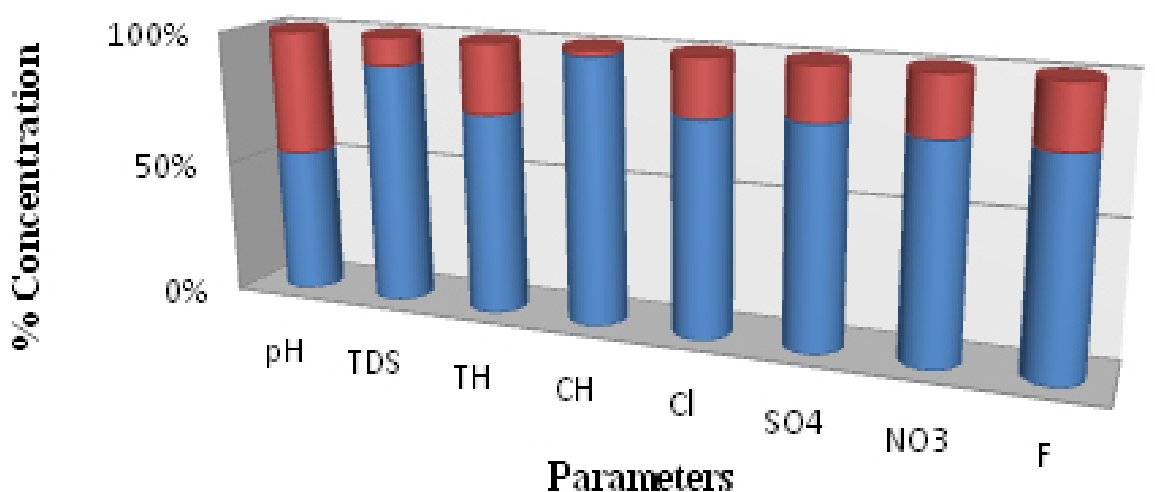

\begin{tabular}{|l|c|c|c|c|c|c|c|c|}
\cline { 2 - 9 } \multicolumn{1}{c|}{} & pH & TDS & TH & CH & Cl & SO4 & NO3 & F \\
\hline$\square$ Post & 8.2 & 4128 & 1000 & 29.4 & 12266 & 122 & 280 & 0.2 \\
\hline$\square$ Pre & 9.6 & 35200 & 2900 & 1179 & 45319 & 500 & 1012 & 0.7 \\
\hline
\end{tabular}

Fig. 3: Leachate Characteristics of Jawaharnagar Municipal Open Dumpsite 
has been calculated by using the standards of drinking water quality recommended by ${ }^{13}$. The WAI (Weighted Arithmetic Index) method has been used for calculation of WQI of the water samples. Further, quality rating or sub index $\left(\mathrm{q}_{n}\right)$ was calculated using the following expression.

$\mathrm{q}_{\mathrm{n}}=100\left[\mathrm{~V}_{\mathrm{n}}-\mathrm{V}_{\text {io }}\right] /\left[\mathrm{S}-\mathrm{V}_{\text {io }}\right]$

$\mathrm{q}_{\mathrm{n}}=$ Quality rating for the $\mathrm{n}^{\text {th }}$ water quality parameter

$V_{n}=$ Estimated value of the $n^{\text {th }}$ parameter $t$ a given sampling station

$S_{n}=$ Standards permissible value of the $n^{\text {th }}$ parameter

$\mathrm{V}_{\mathrm{io}}=$ Ideal value of the $\mathrm{n}^{\text {th }}$ parameter in pure water (i.e.,0 for all other parameters except the parameter $\mathrm{pH}$, where it is 7.0).

Unit weight was calculated by a value inversely proportional to the recommended standard value $S_{n}$ of the corresponding parameter, $\mathrm{W}_{\mathrm{n}}=\mathrm{K} / \mathrm{S}_{\mathrm{n}}$

$\mathrm{W}_{\mathrm{n}}=$ Unit weight for the $\mathrm{n}^{\text {th }}$ parameter

$\mathrm{S}_{\mathrm{n}}=$ Standard value for $\mathrm{n}^{\text {th }}$ parameter

$\mathrm{K}=$ Constant for proportionality

Table 1. GEographical Details of the Study Area

\begin{tabular}{lccccc}
\hline S.No. & $\begin{array}{c}\text { Sampling } \\
\text { Station }\end{array}$ & Latitude & Longitude & Altitude & Dist (km) \\
\hline 1 & Malkaram & 173138 & 783452 & 1858 & 1 \\
2 & Y.S.R. Nagar & 173102 & 783457 & 1859 & 1 \\
3 & Gabbilalpet & 173101 & 783445 & 1877 & 2 \\
4 & Haridaspally & 173139 & 783549 & 1796 & 1 \\
5 & Ahmedguda & 173004 & 783713 & 1703 & 1 \\
6 & IndirammaJn & 173105 & 783652 & 1722 & 2 \\
7 & Dammaiguda & 173012 & 783527 & 1763 & 2 \\
8 & Cheeriyal & 173152 & 783749 & 1770 & 4 \\
9 & Kundanpally & 172956 & 783816 & 1701 & 4 \\
10 & Yadgarpally & 173256 & 783749 & 1735 & 4 \\
11 & Nagaram & 172921 & 783600 & 1703 & 5 \\
12 & Godumkunta & 172932 & 783852 & 1688 & 5 \\
\hline
\end{tabular}

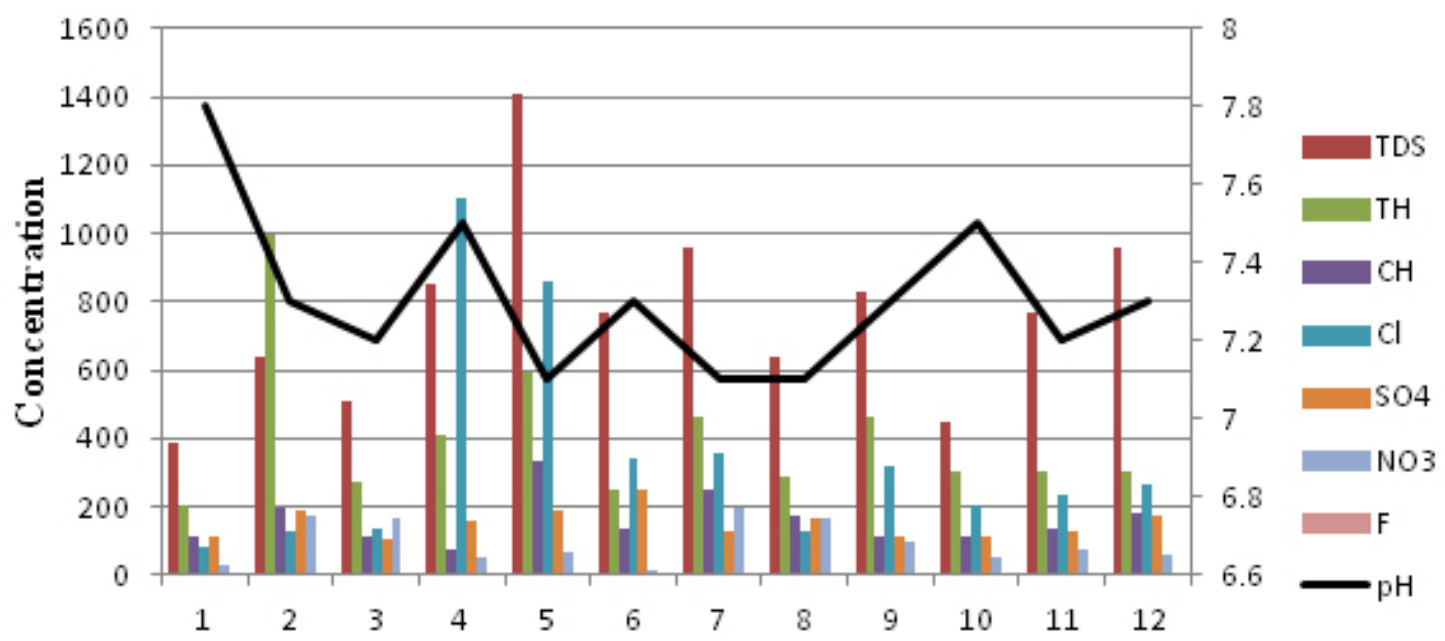

No. of Locations

Fig. 4: Physico-Chemical Parameters of Pre-Monsoon Ground Water 
The overall Water Quality Index was calculated by aggregating the quality rating with the unit weight linearly.

$$
W Q I=\Sigma q_{n} W_{n} / \Sigma W_{n}
$$

The maximum weight of 5 has assigned to the parameters like $\mathrm{NO}_{3}^{-}$. TDS, $\mathrm{Cl}^{-}, \mathrm{F}^{-}$, and $\mathrm{SO}_{4}^{-2}$, due to their major importance in water quality assessment ${ }^{14}$.

\section{RESULTS AND DISCUSSION}

\section{Leachate}

The physico-chemical characteristics of collected leachate around the dumpsite during premonsoon and post-monsoon were analyzed and presented in the (Fig:3). From the figure, it can be observed that $\mathrm{pH}$ is highly alkaline in nature. Alkaline $\mathrm{pH}$ is normally encountered at landfills, 10 years after disposal ${ }^{15}$. Other analyzed parameters like TDS, $\mathrm{TH}, \mathrm{CH}, \mathrm{Cl}^{-}, \mathrm{SO}_{4}{ }^{2-}, \mathrm{NO}_{3}^{-}$and $\mathrm{F}^{-}$were found to have higher concentrations in the leachate collected during pre-monsoon season when compared to post monsoon leachate sample. The results were consistent with ${ }^{16}$.

\section{Major Cations and Anions}

The results of physico-chemical analyses of ground water samples collected during premonsoon and post-monsoon of 2015 were shown in (Fig:4) and (Fig:5) and were compared with the World Health Organization (WHO:2006) as shown in (Table:2). The $\mathrm{pH}$ values of all the ground water samples collected during pre-monsoon and postmonsoon around dumpsite fall within the WHO (2006) limits indicating the alkaline nature. The TDS value of the ground water samples ranged from 384-1408mg/l during pre-monsoon season and from $528-1280 \mathrm{mg} / \mathrm{l}$ which exceeded the permissible limits of $\mathrm{WHO}(2006)$. Concentration of TDS was maximum during pre-monsoon and reduced during post-monsoon which may be due to the dilution of the ions due to precipitation. Total hardness values of water samples ranged from $205-1000 \mathrm{mg} / \mathrm{l}$ during pre-monsoon and $199-664 \mathrm{mg} / \mathrm{l}$ during post-monsoon which were also above the permissible levels of $\mathrm{WHO}(2006)$. The calcium hardness ranged from 75$335 \mathrm{mg} / \mathrm{l}$ during pre-monsoon and $110-499 \mathrm{mg} / \mathrm{l}$ which were above the permissible levels according to $\mathrm{WHO}$ (2006). The chloride values ranged from $78-1100 \mathrm{mg} / \mathrm{l}$ during pre-monsoon and $50-998 \mathrm{mg} / \mathrm{l}$ during postmonsoon which were above the permissible levels of WHO (2006). Highest chloride concentration was observed in GW4 station collected during postmonsoon. The high chloride content in groundwater is from pollution sources such as domestic effluents, fertilizers, septic tanks, and leachates ${ }^{17}$. Sulphates of water samples ranged from $16-250 \mathrm{mg} / \mathrm{l}$ during premonsoon and 49-155mg/l during post-monsoon. All samples fall within permissible limits of WHO (2006) Nitrate values ranged from $13-196 \mathrm{mg} / \mathrm{l}$ during pre-

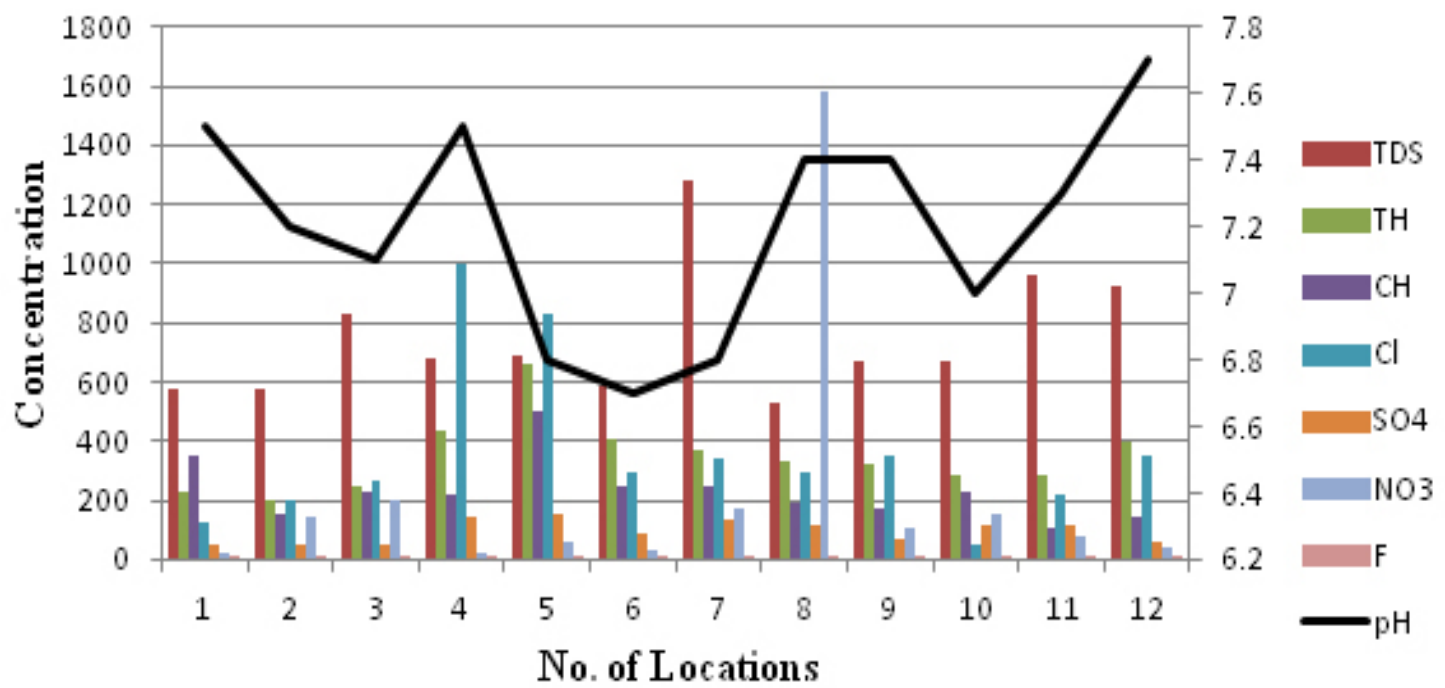

Fig. 5: Physico-Chemical Parameter of Post-Monsoon Ground Water 


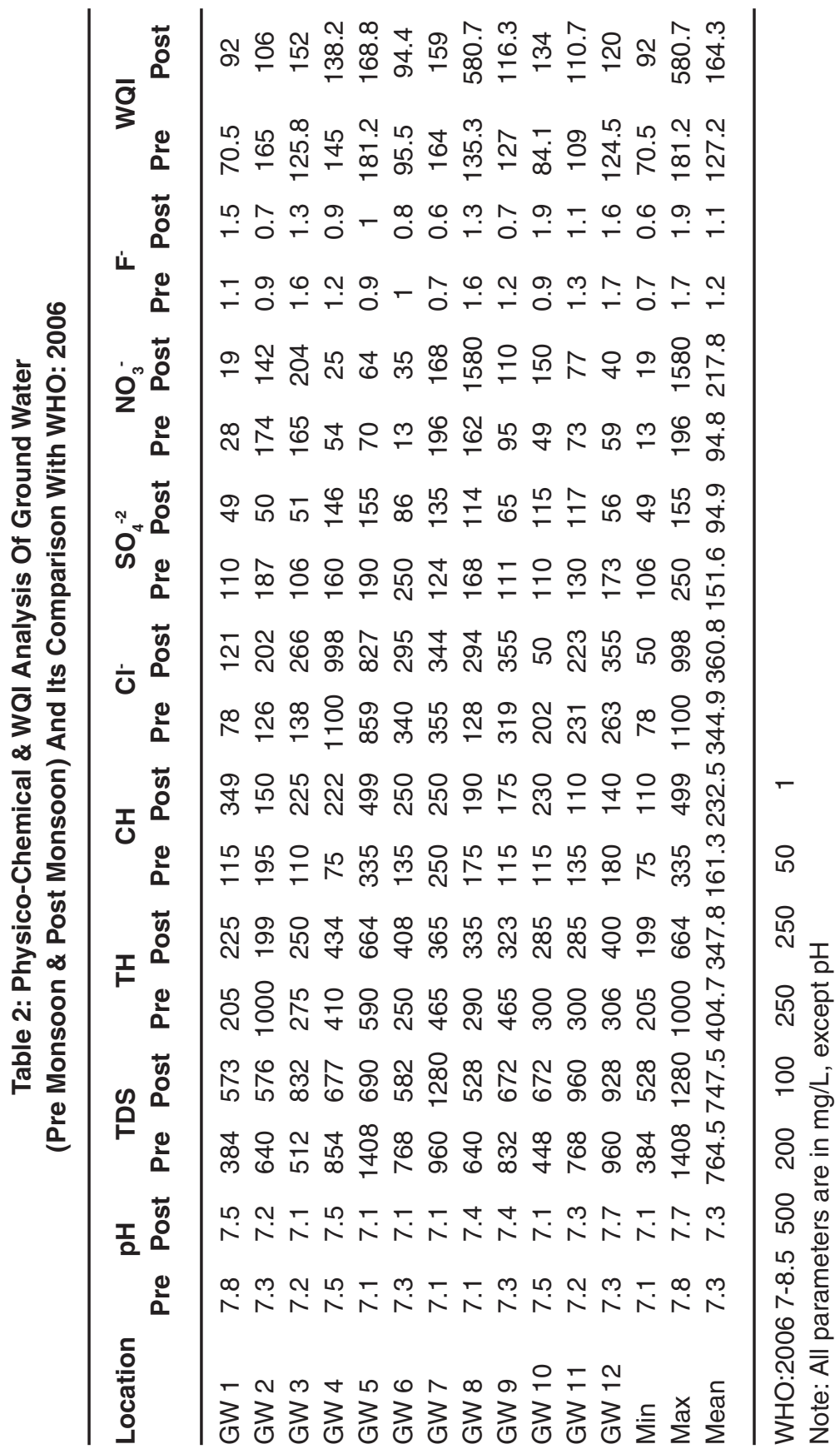


monsoon and 19-1580mg/l during post-monsoon. Most of the water samples exceeded the WHO (2006) limits. Alarmingly, highest value was observed in GW8 (1580mg/l) collected in poultry farm present within the study area during post-monsoon which is a point source of pollution. About $50-80 \%$ of nitrogen is excreted ${ }^{18}$ by the livestock which can be easily leached to the ground water table posing threat to the groundwater resources. In general, other major sources for nitrate in ground-water include domestic sewage, runoff from agricultural fields, and leachate from landfill sites. Higher concentration of $\mathrm{NO}_{3}^{-}$in water causes a disease called "Methaemoglobinaemia" also known as "Blue-baby Syndrome". This disease particularly affects infants that are up to 6 months old ${ }^{19}$. Fluoride values of waters ranged from $1.2-1.7 \mathrm{mg} / \mathrm{l}$ during pre-monsoon and 1.1-1.9mg/l during post-monsoon season. Most of the samples are slightly higher than the permissible (WHO:2006).

Table 3: Computed Average WQI Values Of Pre-Monsoon

Ground Waters Around Jawaharnagar Dumpsite

\begin{tabular}{|c|c|c|c|c|c|c|c|c|}
\hline Parameter & $\begin{array}{l}\text { WHO: } \\
2006 \\
\text { (Sn) }\end{array}$ & $\begin{array}{c}\text { Weight } \\
\text { (Wi) }\end{array}$ & $\begin{array}{c}\text { Relative } \\
\text { Weight } \\
\text { (Wn) }\end{array}$ & $\begin{array}{c}\text { Observed } \\
\text { Value }\end{array}$ & $\begin{array}{c}\text { Standard } \\
\text { Value } \\
\text { (Sn) }\end{array}$ & $\begin{array}{c}\text { Unit } \\
\text { Weight } \\
\text { (Wn) }\end{array}$ & $\begin{array}{c}\text { Quality } \\
\text { Rating } \\
\text { (qn) }\end{array}$ & $W n^{*} q n$ \\
\hline $\mathrm{pH}$ & $7-8.5$ & 4 & 0.125 & 7.3 & 8.5 & 0.125 & 20 & 2.5 \\
\hline TDS & 500 & 5 & 0.156 & 765 & 500 & 0.156 & 153 & 23.8 \\
\hline TH & 200 & 3 & 0.093 & 405 & 200 & 0.093 & 203 & 18.8 \\
\hline $\mathrm{CH}$ & 100 & 2 & 0.062 & 161 & 100 & 0.062 & 161 & 9.9 \\
\hline $\mathrm{Cl}^{-}$ & 250 & 4 & 0.125 & 345 & 250 & 0.125 & 138 & 17.2 \\
\hline $\mathrm{SO}_{4}^{-2}$ & 250 & 4 & 0.125 & 152 & 250 & 0.125 & 61 & 7.6 \\
\hline $\mathrm{NO}_{3}^{-}$ & 50 & 5 & 0.156 & 95 & 50 & 0.156 & 190 & 29.6 \\
\hline $\mathrm{F}^{-}$ & 1 & 1 & 0.156 & 1.2 & 1 & 0.156 & 120 & 18.7 \\
\hline \multirow[t]{2}{*}{ Total } & & 32 & 0.998 & & & & & \\
\hline & & & & & & $\Sigma W n=0.998$ & & $\begin{array}{c}\Sigma W^{*} \\
q n=136.5\end{array}$ \\
\hline
\end{tabular}

All parameters are in $\mathrm{mg} / \mathrm{L}$, except for $\mathrm{pH} \&$ TDS.

Table 4. Computed Average WQI Values of Post-Monsoon

Ground Waters Around Jawaharnagar Dumpsite

\begin{tabular}{lcccccccc}
\hline Parameter & $\begin{array}{c}\text { WHO: } \\
\mathbf{2 0 0 6} \\
(\mathbf{S n})\end{array}$ & $\begin{array}{c}\text { Weight } \\
\text { (Wi) }\end{array}$ & $\begin{array}{c}\text { Relative } \\
\text { Weight } \\
\text { (Wn) }\end{array}$ & $\begin{array}{c}\text { Observed } \\
\text { Value }\end{array}$ & $\begin{array}{c}\text { Standard } \\
\text { Value } \\
\text { (Sn) }\end{array}$ & $\begin{array}{c}\text { Unit } \\
\text { Weight } \\
\text { (Wn) }\end{array}$ & $\begin{array}{c}\text { Quality } \\
\text { Rating } \\
\text { (qn) }\end{array}$ & Wn*qn $^{*}$ \\
\hline $\mathrm{pH}$ & $7-8.5$ & 4 & 0.125 & 7.3 & 85 & 0.125 & 20 & 2.5 \\
$\mathrm{TDS}$ & 500 & 5 & 0.156 & 748 & 500 & 0.156 & 150 & 23.4 \\
$\mathrm{TH}$ & 200 & 3 & 0.093 & 348 & 200 & 0.093 & 174 & 16.1 \\
$\mathrm{CH}$ & 100 & 2 & 0.062 & 233 & 100 & 0.062 & 233 & 14.4 \\
$\mathrm{Cl}^{-}$ & 250 & 4 & 0.125 & 361 & 250 & 0.125 & 144 & 18 \\
$\mathrm{SO}_{4}^{-2}$ & 250 & 4 & 0.125 & 95 & 250 & 0.125 & 38 & 4.75 \\
$\mathrm{NO}_{3}^{-}$ & 50 & 5 & 0.156 & 218 & 50 & 0.156 & 436 & 68 \\
$\mathrm{~F}^{-}$ & 1 & 1 & 0.156 & 1.1 & 1 & 0.156 & 110 & 17.1 \\
$\mathrm{Total}^{-5}$ & & 32 & 0.998 & & & $\Sigma W n=0.998$ & & $\Sigma \mathbf{W n}^{*}$ \\
& & & & & & & & qn $=164.4$ \\
\hline
\end{tabular}


Water Quality Index (WQI)

Water quality index developed for the groundwater samples collected during pre-monsoon and post-monsoon indicated that there is a wide variation from station to station. In this study, WQI values were 136.5 and 164.4 in pre and post monsoon respectively (Table:3) and (Table:4). According to ${ }^{20}, 75 \%$ of water samples fall in "Poor" category, 25\% fall in "Good" category collected during pre-monsoon. Similarly, $75 \%$ of water samples fall in "Poor" category, $16.9 \%$ of water samples fall in "Good" category and $18.3 \%$ of water samples fall in "Unsuitable" category collected during post-monsoon season (Table:5).

Correlation Analysis Of Pre-Monsoon And PostMonsoon Ground Water Parameters

Correlation is a method used to evaluate the degree of interrelation and association between two variables ${ }^{21}$. A correlation of 1 indicates a perfect

Table 5: Classification Of Pre-Monsoon And Post-Monsoon Ground Water Quality Based On WQI Value

\begin{tabular}{lccc}
\hline $\begin{array}{l}\text { WQI } \\
\text { Value }\end{array}$ & $\begin{array}{c}\text { Water } \\
\text { Quality }\end{array}$ & $\begin{array}{c}\text { Percentage of } \\
\text { GW Samples } \\
\text { Pre Monsoon }\end{array}$ & $\begin{array}{c}\text { Percentage of } \\
\text { GW Samples } \\
\text { Post Monsoon }\end{array}$ \\
\hline$<50$ & Excellent & Nil & Nil \\
$50-100$ & Good & $25 \%$ & $16.9 \%$ \\
$100-200$ & Poor & $75 \%$ & $75 \%$ \\
$200-300$ & Very Poor & Nil & Nil \\
$>300$ & Unsuitable & Nil & $8.3 \%$ \\
\hline
\end{tabular}

Table 6. Correlation Matrix Of Pre-Monsoon Ground Water

\begin{tabular}{lcccccccc}
\hline & $\mathbf{p H}$ & TDS & TH & $\mathbf{C H}$ & $\mathbf{C l}^{-}$ & $\mathbf{S O}_{4}^{-2}$ & $\mathrm{NO}_{3}^{-}$ & $\mathbf{F}^{-}$ \\
\hline $\mathrm{pH}$ & 1 & & & & & & & \\
$\mathrm{TDS}$ & -0.56239 & 1 & & & & & & \\
$\mathrm{TH}$ & -0.24759 & 0.297768 & 1 & & & & & \\
$\mathrm{TH}$ & -0.59079 & 0.730952 & 0.452917 & 1 & & & & \\
$\mathrm{Cl}$ & -0.05663 & 0.66473 & 0.144608 & 0.188295 & 1 & & \\
$\mathrm{SO}_{4}^{-2}$ & -0.2597 & 0.413605 & 0.242431 & 0.322037 & 0.27596066 & 1 & \\
$\mathrm{NO}_{3}^{-}$ & -0.59171 & -0.01683 & 0.454436 & 0.309294 & -0.2714739 & -0.2306 & 1 \\
$\mathrm{~F}^{-}$ & -0.10585 & -0.17716 & -0.43997 & -0.3552 & -0.2200465 & -0.09241 & 0.021369 & 1 \\
\hline
\end{tabular}

Table 7. Correlation Matrix Of Post-Monsoon Ground Water

\begin{tabular}{lcccccccc}
\hline & pH & TDS & TH & CH & $\mathbf{C l}^{-}$ & SO $_{4}^{-2}$ & $\mathrm{NO}_{3}^{-}$ & $\mathbf{F}^{-}$ \\
\hline $\mathrm{pH}$ & 1 & & & & & & & \\
$\mathrm{TDS}$ & -0.1574 & 1 & & & & & & \\
$\mathrm{TH}$ & -0.31802 & 0.064187 & 1 & & & & & \\
$\mathrm{TH}$ & -0.45206 & -0.1743 & 0.617686 & 1 & & & & \\
$\mathrm{Cl}$ & 0.013082 & -0.00072 & 0.766779 & 0.38716907 & 1 & & & \\
$\mathrm{SO}_{4}^{-2}$ & -0.37461 & 0.228926 & 0.658442 & 0.35664521 & 0.596911 & 1 & & \\
$\mathrm{NO}_{3}^{-}$ & 0.142199 & -0.26452 & -0.08622 & -0.1554513 & -0.12873 & 0.132874 & 1 & \\
$\mathrm{~F}^{-}$ & 0.331722 & -0.16816 & -0.18182 & 0.01231033 & -0.37028 & -0.16887 & 0.130479 & 1 \\
\hline
\end{tabular}


positive relationship between two variables. A correlation of -1 indicates that one variable changes inversely with relation to the other. A correlation of zero indicates that there is no relationship between the two variables. Correlation matrix of pre and post monsoon ground water parameters of the study area are represented in (Table:6) and (Table:7). In premonsoon season, the influence of TDS on $\mathrm{CH}$ and $\mathrm{Cl}^{-}$were observed to have positive correlation. The positive correlation between TDS and $\mathrm{CH}(\mathrm{r}=0.730)$ is normal and is responsible to a large extent of calcium hardness of water. Positive correlation of TDS with $\mathrm{Cl}(\mathrm{r}=0.66)$ is shown in (Fig:6). In postmonsoon season, $\mathrm{TH}$ was positively correlated with $\mathrm{Cl}(\mathrm{r}=0.766) \mathrm{CH}(\mathrm{r}=0.617)$, and $\mathrm{SO}_{4}{ }^{-2}(\mathrm{r}=0.658)$ (Fig:7) and (Fig:8). This result indicates that there was great reliance of hardness on calcium, chlorides and sulphates.

\section{CONCLUSION}

Municipal landfills and open dumps have been posing a threat to a greater extent by contaminating the surroundings especially the ground water resources. The study reveals that the unconditional dumping of the wastes in Jawaharnagar dumpsite and establishment of inappropriate leachate collecting systems has

TDS Vs Cl

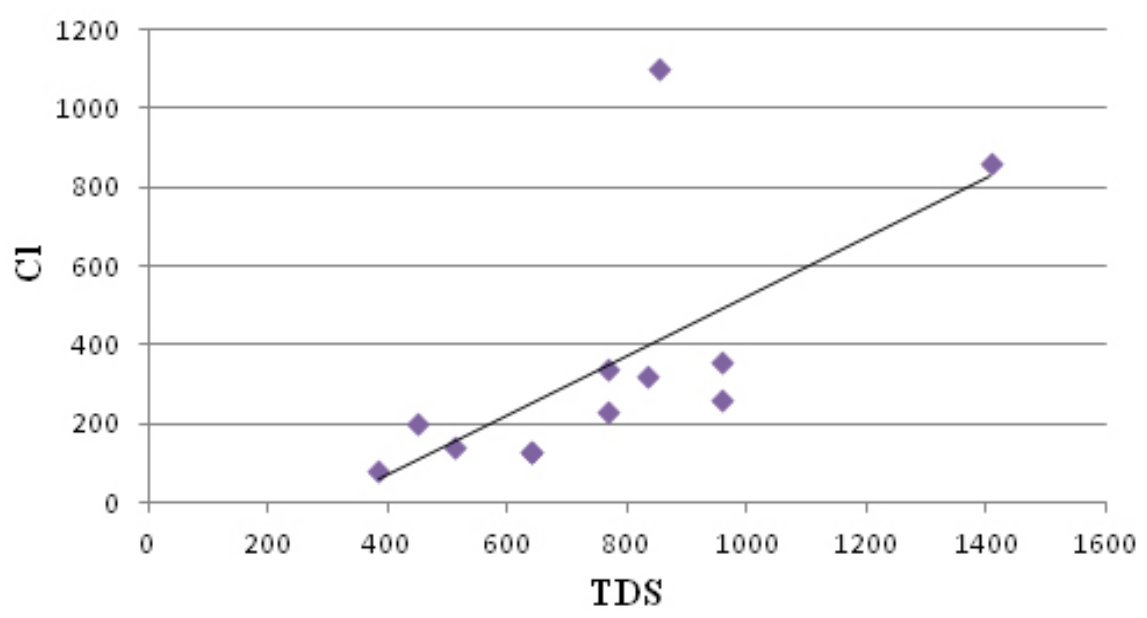

Fig. 6: Correlation between TDS and $\mathrm{Cl}^{-}(\mathrm{mg} / \mathrm{l})$ Parameters of Pre-Monsoon Ground Water

$\mathrm{TH} \mathrm{Vs} \mathrm{Cl}^{-}$

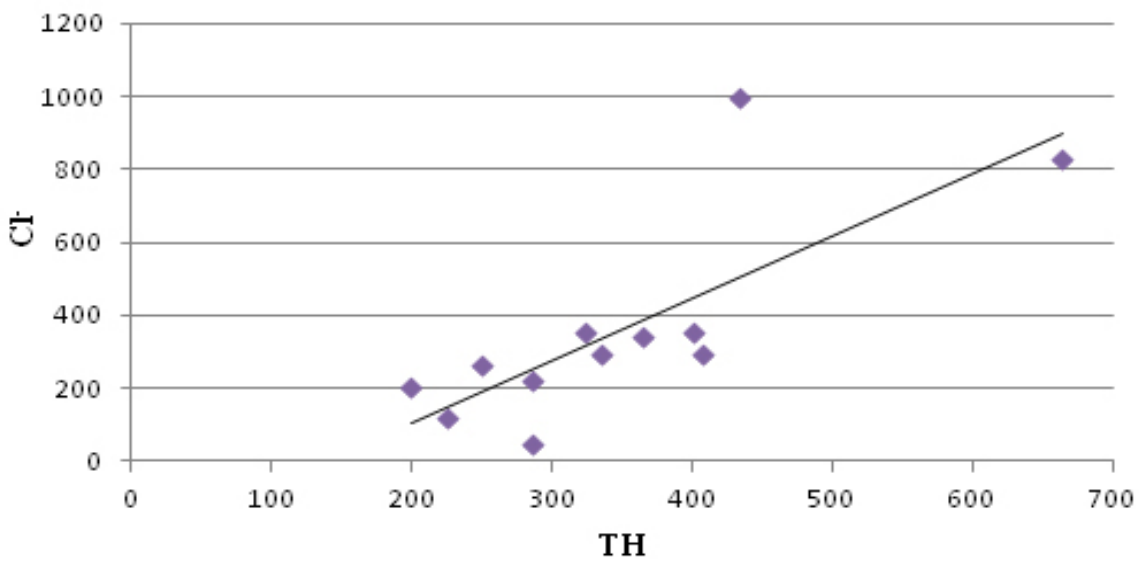

Fig. 7: Correlation between TH and $\mathrm{Cl}^{-}(\mathrm{mg} / \mathrm{l})$ Parameters of Post-Monsoon Ground Water 


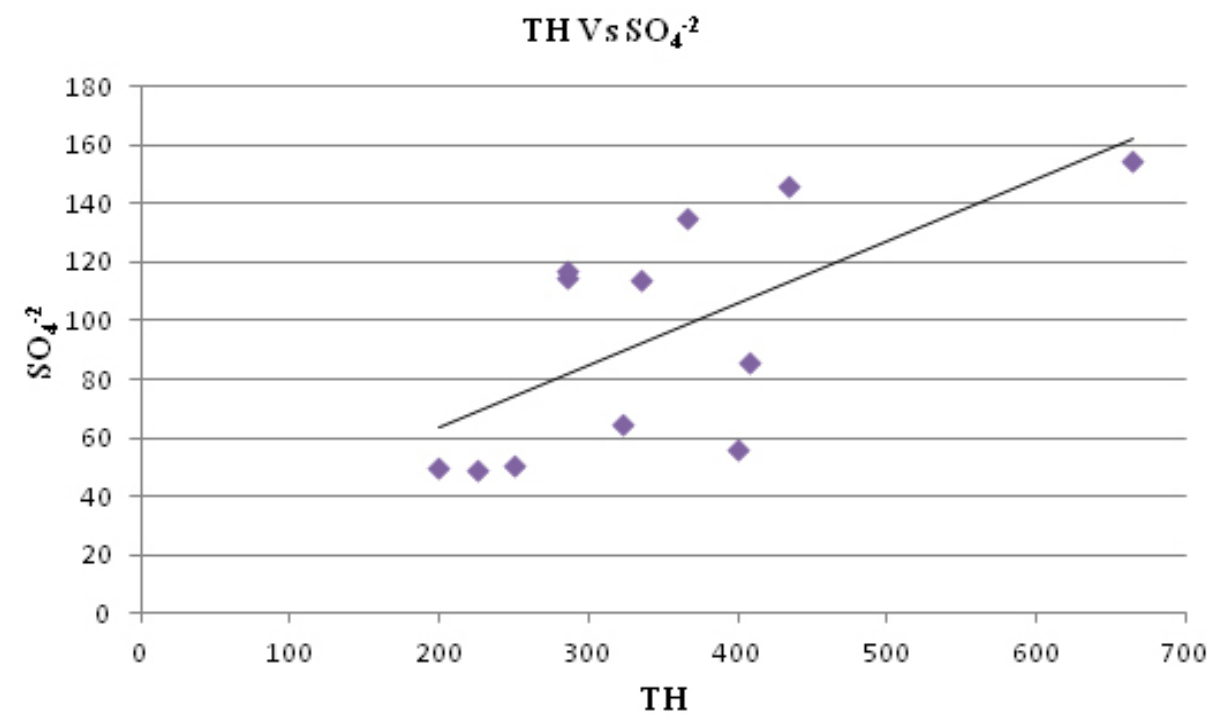

Fig. 8: Correlation between TH and $\mathrm{SO}_{4}^{-2}(\mathrm{mg} / \mathrm{l})$ Parameters of Post-Monsoon Ground Water

extremely polluted the ground waters over time. The findings conclude that, most of the water samples were found to be unsuitable for drinking purpose except for few and therefore puts emphasis on enforcement of governmental policies on waste disposal and management, citing of dumpsites far away from residential areas to minimize pollution, waste sorting and treatment before disposal and constructing well engineered landfills to avoid the leachate percolation into the ground waters.

\section{ACKNOWLEDGEMENT}

The study would not have been possible without the support and assistance of Dr. M. Ramana Kumar, Lab In-charge, Department of Applied Geochemistry,University College of Sciences, Osmania University, Hyderabad.

\section{REFERENCES}

1 Akolkar A. B. Asia Pacific Regional Workshop on Sustaianable Waste Management, 16,(2002).

2. Ettler V Mihaljevic M., Matura M., Sebek O., Bezdicka P. Temporal variation of trace elements in waters polluted by municipal solid waste landfill leachate. Bulletin of Environmental Contamination and Toxicology, 80: 274-279.(2008).

3. Ustohalova V,Tim Ricken, RenatusWidmann. Estimation of landfill emission lifespan using process oriented model. Waste Management, 26, 442-450(2006).

4. Bodzek V, £obos-Moysa M.E, and Zamorowskaet. M. Removal of organic compounds from municipal landfill leachate in a membrane bioreactor Desalination, 198:1623,(2006).

5. Tiwari, T.N. and Mishra.M.A. A Preliminary assignment of water quality index of major Indian rivers. Indian Journal of Environmental Protection, 5: 276-279,(2013).

6. Anju Anil Kumar, Dipu Sukumaran, Salom GnanaThanga Vincent. Effect of Municipal Waste of Ground Water Quality of Thiruvananthapuram District, Kerala, India, Applied Ecology and Environmental Sciences, 3(5): pp 151-157,(2015).

7. S.Sharma and Chippa, Global Journal of Environmental Science and Management, 
2(1):79-86(2016).

8. Badmus B.S, Ozebo V.C, Idowu O.A, Ganivu S.A, Olurin O.T. Seasonal Variations of Physico Chemical Properties and Quality Index of Groundwater of Hand-Dug Wells Around Ajakanga Dump Site in Southwestern Nigeria. Research Journal of Physics, 9:1-10. (2015).

9. IshakuJ. M.. Assessment of Ground Water Quality Index for Jimetayola Area, Northeastern Nigeria, Journal of Geology and Mining Research, 3(9): pp 219-231(2011).

10. Abdulrafiu O Majolagbe Adebola A. Adeyi and Oladele Osibanjo. Vulnerability assessment of groundwater pollution in the vicinity of an active dumpsite (Olusosun), Lagos, Nigeria.Chemistry International 2(4):232241,(2016).

11. American Public Health Association(APHA),. Standard method for the examination of water and waste water(21st edition) Washington D.C. (2005).

12. Chapman D A guide to the use of BIOTA sediments and water in environmental monitoring water quality assessments UNE-SCO/WHO/UNEP. Chapman and Hall, London, pp 371-460(1992)

13. WHO, Guidelines for Drinking-Water Quality, Geneva, Switzerland.(2006).

14. Srinivasamoorthy K, Chidambaram S and Vasanthavigar. Geochemistry of fluorides in groundwater: Salem district, Tamilnadu, India, Journal of Environmental Hydrology, 16: Paper 25 August (2008).
15. El-Fadel M, Bou-Zeid E, Chahine W, Alayli B. Temporal variation of leachate quality from pre-sorted and baled municipal solid waste with high organic and moisture content. Waste Manag(Oxford), 22(3):269-282,(2002).

16. Esakku.S, Obuli Karthik, Kurian Joseph, Nagendran. R Seasonal Variations in Leachate Characteristics from Municipal Solid Waste Dumpsites in India and SrilankaProceedings of the International Conference on Sustainable Solid Waste Management, 5 - 7, Chennai, India. pp.341-347(2007).

17. McCarthy MF. Should we restrict chloride rather than sodium, Med Hypotheses 63:138148, (2004).

18. Arogo.J, Westerman, P.W., Heber, A.J., Robarge, W.P. and Classen, J.J. Ammonia in animal production - a review. Paper number 014089, 2001 presented at the ASAE Annual Meeting July 30-August 1, 2001, Sacramento, USA. American Society of Agricultural and Biological Engineers. 2001.

19. Kapil DM, Mamta K, Sharma DK. Hydrochemical analysis of drinking water quality of Alwar District Rajasthan. Nature Sci 7(2):30-39,(2009).

20. Ramakrishna C.H, Rao D.M, Rao K.S, Srinivas N. Studies on ground water quality in slums of Visakhapatnam, Andhra Pradesh, Asian J. Chem., 21(6):4246-4250,(2009).

21. Nair GA, Mohamed Al, Premkumar K. Physico chemical parameters and correlation coefficents of ground waters of North-East Libya. Pollut Res 24(1):1-6,(2005). 